\title{
PENGARUH STRATEGI THINK TALK WRITE (TTW) TERHADAP KEMAMPUAN PEMAHAMAN KONSEP PADA PEMBELAJARAN MATEMATIKA
}

\author{
Intan $^{1}$, M. Hasbi Ashiddiqi ${ }^{2}$, Rieno Septra Nery ${ }^{3}$ \\ Pendidikan Matematika Universitas Islam Negeri Raden Fatah Palembang \\ 1email : intnab@gmail.com \\ 2email: hasbiashiddiqi66@gmail.com \\ 3 email: rienosn@gmail.com
}

\begin{abstract}
This research aims to determine the effect of using think talk write strategy to the concepts comprehension ability to mathematics course of MTs $N 2$ Model Palembang. The type of this research is true experimental design with posttest control group design. The populations in this research is all of the seventh grade students of MTs N 2 Model Palembang. This research took two classes as the sample taken using cluster random sampling technique. The research was conducted of four meetings.The data obtained from the test is used to test the research hypothesis by using t-test. From the data analysis, it shows $t_{\text {critical }}$ is 2,544 with $\alpha$ is 0,05 and it also was obtained $t_{\text {table }}=1,6735$, which means $t_{\text {critical }}$ is higher than $t_{\text {table }}$ which is 2,544 is higher than 1,6735. It showed that $\mathrm{Ha}$ is accepted which means that there a think talk write (ttw) strategy influence on the concepts comprehension ability in mathematics course at MTs $N 2$ Model Palembang.
\end{abstract}

Keywords: Think Talk Write (TTW) Strategy, Concepts Comprehension Ability

\begin{abstract}
Abstrak
Penelitian ini bertujuan untuk mengetahui pengaruh strategi think talk write terhadap pemahaman konsep pada pembelajaran matematika di MTs N 2 Model Palembang. Jenis penelitian yang digunakan adalah true exprimental design dengan desain posttest control group design. Populasi yang digunakan adalah seluruh siswa kelas VII yang ada di MTs N 2 Model Palembang. Penelitian ini mengambil dua kelas sebagai sampel yang diambil dengan menggunakan teknik cluster random sampling. Penelitian itu dilaksanakan sebanyak empat kali pertemuan. Data yang diperoleh dari hasil tes digunakan untuk menguji hipotesis penelitian dengan menggunakan uji-t. Dari hasil analisis diperoleh $t_{\text {hitung }}$ $=2,544$ dan dengan $\alpha=0,05$ diperoleh $t_{\text {tabel }}=1,6735$ yang berarti $t_{\text {hitung }}>t_{\text {tabel }}$ yaitu 2,544 $>1,6735$. Hal ini menunjukkan bahwa Ha diterima artinya terdapat pengaruh strategi Think Talk Write (TTW) terhadap kemampuan pemahaman konsep pada pembelajaran matematika di MTs N 2 Model Palembang.
\end{abstract}

Kata Kunci: Strategi Think Talk Write (TTW), Kemampuan Pemahaman Konsep 


\section{PENDAHULUAN}

Matematika merupakan induk dari ilmu pengetahuan, tanpanya perkembangan ilmu pengetahuan dan teknologi tidak akan berkembang dengan pesat, dan karakteristik materi matematika bersifat abstrak, logis, sistematis, penuh dengan lambang-lambang, simbol dan rumus. Penjelasan-penjelasan mengenai matematika tersebut juga dijelaskan dalam al -Qur'an surah Al-Qamar, ayat 49 dinyatakan:

Artinya" :Sesungguhnya kami menciptakan segala sesuatu dengan ukuran"

Dari pengertian ayat Al-Qur'an di atas diketahui bahwa segala ilmu pengetahuan yang diperoleh tidak hanya bersifat kualitatif, melainkan juga bersifat kuantitatif dan dapat diperlakukan datanya secara matematis (ilmu matematika).) Baiquni, 1994)

Berdasarkan hasil pengamatan PPLK II peneliti pada kelas VII di MTs N 2 Model Palembang bahwa siswa-siswa mengalami beberapa permasalahan seperti sulitnya mengungkapkan kembali apa yang telah dikomunikasikan kepada siswa, sulit menyelesaikan soal yang berbeda dari contoh yang diberikan guru sebelumnya, dan sulit menyelesaikan soal dengan tepat sesuai dengan prosedur. Dilihat dari permasalahan di atas, dapat disimpulkan bahwa siswa kelas VII MTs N 2 Model Palembang masih kurangnya pemahaman konsep pada pembelajaran matematika. Karena, kemampuan pemahaman konsep terhadap matematika adalah bagian yang sangat penting dalam proses pembelajaran matematika. Dimana "pemahaman merupakan kemampuan mendasar yang harus dimiliki siswa dalam belajar konsep-konsep matematika yang lebih lanjut" (Kiftiyah, Yudyanto, \& Sutopo, 2014, hal. 1). Sedangkan, pemahaman konsep merupakan kemampuan yang ditujukan siswa dalam memahami konsep dan dalam melakukan prosedur (algoritma) secara luwes, akurat, efisien, dan tepat (Yustisia dalam (Septiani, 2015, hal. 16). Maka, salah satu solusi dari permasalahan tersebut adalah menerapkan strategi pembelajaran Think Talk Write.

Pada tahap think, peserta didik berusaha memikirkan konsep yang dipelajari secara mandiri kemudian pada tahap talk peserta didik mengkomunikasikan pemikiran dan pendapatnya kepada teman-temannya sehingga terbentuk pemahaman konsep. Disamping itu, diskusi dapat menumbuhkan keaktifan peserta didik dalam mempelajari konsep matematika. Tahap write menambah peserta didik dalam memahami konsep karena menulis membutuhkan pemikiran ulang mengenai apa yang telah didiskusikan (Hinayah, 
2010, hal. 3). Berdasarkan penjelasan tersebut dapat dilihat bahwa tahapan-tahapan yang ada pada strategi tersebut, memiliki hubungan dalam mengatasi permasalahan terhadap kemampuan pemahaman konsep. Oleh karena itu, peneliti ingin melihat adakah "Pengaruh Strategi Think Talk Write terhadap Kemampuan Pemahaman Konsep di MTs N 2 Model Palembang."

\section{METODE PENELITIAN}

Penelitian ini menggunakan penelitian dengan metode penelitian eksperimen yaitu true eksperiment design dengan desain yang digunakan adalah posttest only control design (Sugiyono, 2013, hal. 112). Variabel dalam penelitian ini adalah variabel bebas yaitu pembelajaran strategi Think Talk Write $(T T W)$ dan variabel terikat yaitu kemampuan pemahaman konsep matematis siswa. Adapun sampel dalam penelitian ini diambil dengan menggunakan teknik cluster random sampling, dari 6 kelas yang ada di MTs N 2 Model Palembang, diambil dua kelas (dilakukan secara diundi) untuk dijadikan sampel yaitu kelas VII.2 sebagai kelas eksperimen dan VII.1 sebagai kelas kontrol.

Teknik atau cara-cara yang dapat digunakan oleh peneliti untuk mengumpulkan data adalah observasi dan tes. Observasi dilakukan selama proses pembelajaran berlangsung untuk melihat apakah siswa telah melalui tahap-tahap yang ada pada strategi think talk write, sedangkan tes dilakukan pada pertemuan terakhir yaitu soal posttest untuk mengukur kemampuan pemahaman konsep siswa dengan soal berbentuk uraian. Instrumen yang baik harus memenuhi dua persyaratan penting yaitu valid dan reliabel (Arikunto, 2013, hal. 211), maka peneliti menggunakan korelasi product moment untuk melihat kevalidan dari tes, dan peneliti menggunakan rumus Alpha Cronbach melihat kereabilitas dari tes. Setelah mengumpulkan data, peneliti selanjutnya menganalis data tersebut dengan uji prasyarat dan uji hipotesis. Dimana uji prasyarat yaitu uji normalitas (uji liliefors) dan uji homogenitas (uji-F), Setelah melalui uji prasyarat tersebut, data yang terkumpul dianalisis menggunakan uji hipotesis yaitu uji t jika data berasal dari populasi yang berdistribusi normal dan varians dalam populasi bersifat homogen.

\section{HASIL PENELITIAN}

Penelitian ini dilakukan dengan tiga tahap, yaitu tahap persiapan, tahap pelaksanaan, dan tahap akhir. Pada tahap persiapan, peneliti mempersiapkan instrumen penelitian (Rencana Pelaksanaan Pembelajaran (RPP), Lembar Kerja Siswa (LKS), 
Lembar Observasi dan soal posttest dengan mengkonsultasikan instrumen dengan dosen pembimbing dan pakar (validator). Pakar yang terlibat dalam validasi instrumen penelitian adalah dua orang dosen Pendidikan Matematika yaitu TG dan RSU, serta satu orang guru mata pelajaran matematika yaitu Ibu KHY, S.Pd. Setelah dilakukan uji validitas pakar, peneliti juga mengujicobakan soal posttest kepada siswa kelas VIII sebanyak 10 orang.

Pada Uji Validitas posttest, teknik yang digunakan untuk mengetahui kesejajaran adalah teknik korelasi product moment dengan angka kasar (Arikunto, 2013, hal. 87). Setelah dilakukan perhitungan pada taraf $\alpha=5 \%$ dengan $n=10$ diperoleh $r_{\text {tabel }}=0.6319$ dengan setiap koefisien butir soal $r_{\text {hitung }}\left(r_{x y}\right)$ lebih besar dari $r_{\text {tabel }}$. Dengan demikian semua butir soal tes matematika tersebut dinyatakan valid dan dapat digunakan pada penelitian. Sedangkan pada Uji Reliabilitas Posttest, suatu penelitian dinyatakan reliabilitas apabila penelitian tersebut dapat dikatakan konsisten, tetap ataupun sama walaupun diuji dengan waktu yang berbeda, untuk menghitung reliabilitas menggunakan rumus Alpha sebagai berikut (Arikunto, 2010, hal. 239). Kemudian hasil $\mathrm{r}_{11}$ dibandingkan dengan harga $\mathrm{r}$ product moment dengan taraf signifikan 5\%. Jika $\mathrm{r}_{\mathrm{xy}}>\mathrm{r}_{\text {tabel }}$ dengan $\alpha=5 \%$ maka item soal dikatakan reliabel atau dengan kata lain jika $r_{x y}<r_{\text {tabel }}$ maka item soal tidak reliabel. Setelah dilakukan perhitungan, diperoleh $\mathrm{r}_{\text {hitung }}=0,7524$, sedangkan harga $r_{\text {tabel }}$ dengan jumlah $n=10$ untuk taraf signifikan $\alpha=5 \%$ adalah 0,6319 maka $r_{\text {hitung }}>r_{\text {tabel }}$, sehingga butir soal yang diujicobakan reliabel.

Pada tahap pelaksanaan, peneliti melakukan penelitian di MTs N 2 Model Palembang pada tanggal 23 November 2016 s/d 01 Desember 2016 dengan 4 pertemuan dari masing-masing kelas. Pada 3 pertemuan peneliti melakukan observasi hanya pada kelas eksperime. Pada pertemuan terakhir dari masing-masing kelas, peneliti melaksanakan tes dengan soal posttest yang sama. Pada tahap akhir, peneliti menganalisis data yang sudah dikumpulkan seperti observasi dan soal posttest.

Hasil analisis data instrumen hasil observasi yang dilakukan oleh 3 observer, yaitu IAM, IM, dan DRS pada pertemuan pertama, kedua, dan ketiga untuk mengetahui seberapa besar siswa telah melakukan tahap-tahap yang ada pada strategi think talk write adalah dengan menggunakan 5 skala yaitu $1=$ sangat buruk, $2=$ buruk, $3=$ sedang, $4=$ bagus, 5 = sangat bagus. Berikut ini, rincian rekapitulasi hasil observasi, yaitu dapat dilihat pada tabel 3 . 
Tabel 3. Perhitungan Hasil Observasi

\begin{tabular}{|c|c|c|c|}
\hline Pertemuan Ke- & Tahap & Skor & Rata-rata \\
\hline \multirow{4}{*}{1} & Think & 60 & 60 \\
\cline { 2 - 4 } & Talk & 59 & \\
\cline { 2 - 4 } & Write & 60 & \\
\hline \multirow{4}{*}{2} & Think & 66 & 68 \\
\cline { 2 - 4 } & Talk & 69 & \\
\cline { 2 - 4 } & Write & 69 & \\
\hline \multirow{4}{*}{3} & Think & 67 & \\
& Talk & 77 & \\
\cline { 2 - 4 } & Write & 78 & \\
\hline
\end{tabular}

Dilihat dari tabel di atas, menunjukkan bahwa rata-rata hasil observasi siswa mengalami peningkatan pada tiap pertemuannya. Pertemuan pertama, siswa belum terbiasa melakukan pembelajaran matematika menggunakan strategi TTW sehingga memperoleh rata-rata observasi dengan nilai 60. Pertemuan kedua, siswa mulai terbiasa, dan siswa lebih memahami setiap tahapan yang digunakan strategi TTW sehingga memperoleh peningkatan rata-rata observasi dengan nilai 68. Pertemuan ketiga, siswa terlihat lebih santai, tanpa peneliti memberikan arahan, siswa sudah melakukan setiap tahapan pada strategi TTW dengan baik sehingga memperoleh peningkatan rata-rata observasi dengan nilai 74. Untuk mengetahui data berdistribusi normal atau tidak maka peneliti menggunakan uji liliefors. Data yang didapat adalah $\mathrm{L}_{0}=0,1292$, sedangkan Ltabel $=0,1658$, karena $\mathrm{L}_{0}$ kurang dari $\mathrm{L}_{\text {tabel }}(0,1292<0,1658)$. Maka data nilai post-test kelas eksperimen berdistribusi normal. Data yang didapat adalah $\mathrm{L}_{0}=0,1151$, sedangkan Ltabel $=0,1634$, karena $\mathrm{L}_{0}$ kurang dari $\mathrm{L}_{\text {tabel }}(0,1151<0,1634)$. Maka data nilai post-test kelas kontrol berdistribusi normal.

Untuk uji-t nilai post-test guna mengetahui perbedaan dari data hasil post-test kelas eksperimen dan kelas kontrol. Data yang didapat adalah $t_{\text {hitung }}=2,544$, sedangkan $t_{\text {tabel }}=$ 1,6735. Karena $t_{\text {hitung }}$ lebih besar dari $t_{\text {tabel }}(2,544>1,6735)$ maka berarti ada pengaruh strategi Think Talk Write (TTW) terhadap kemampuan pemahaman konsep pada pembelajaran matematika di MTs N 2 Model Palembang. 


\section{PEMBAHASAN}

Penelitian ini dilakukan dengan menggunakan observasi dan tes. Observasi dilakukan bertujuan untuk mengetahui apakah siswa telah melakukan tahap-tahap yang ada pada strategi TTW, observasi dilakukan oleh observer, observer mengamati dan menilai sesuai dengan indikator-indikator yang telah dibuat peneliti pada lembar observasi. Sedangkan, tes dilakukan bertujuan untuk mengukur pemahaman konsep siswa pada kelas eksperimen yang diberi perlakuan strategi TTW dan kelas kontrol sebagai pembanding. Tes dilakukan pada akhir pertemuan, yaitu pemberian tes akhir dengan soal posttest. Soal-soal tersebut bertujuan untuk melihat 4 indikator pemahaman konsep yaitu menyajikan ulang sebuah konsep, menyajikan dalam berbagai bentuk representasi matematis, menggunakan, memanfaatkan, dan memilih prosedur, serta mengaplikasikan konep atau algoritma pemecahan masalah. Penjelasan lebih rinci mengenai soal posttest yang diberikan kepada siswa untuk mengukur pemahaman konsep siswa dijelaskan sebagai berikut:

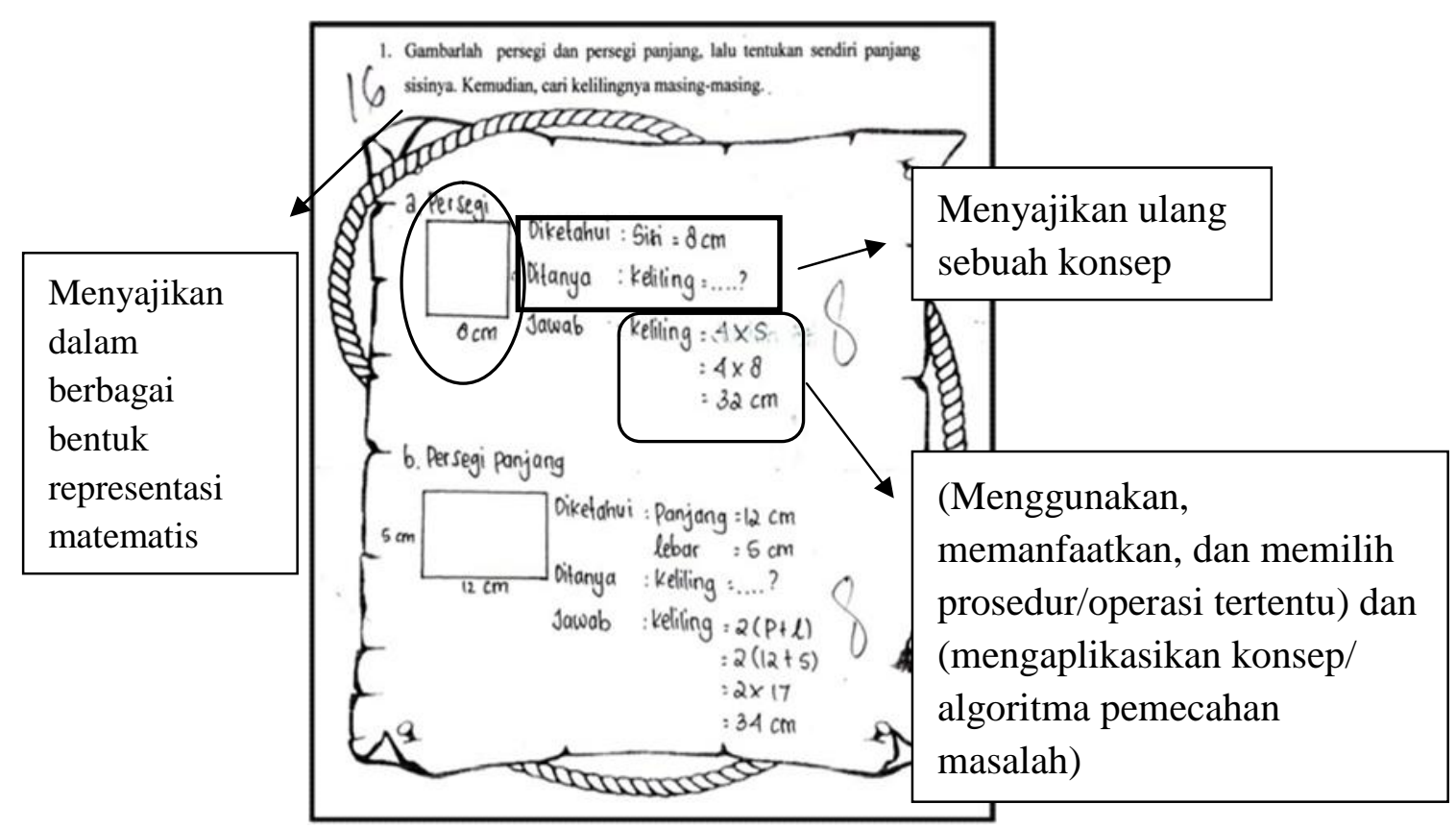

Gambar 1 Jawaban siswa kelas Eksperimen soal posttest ke-1 
Soal ini tidak memiliki ketentuan sendiri. Kesalahan yang sering muncul pada soal ini hanya pada bagian menghitung keliling (hasil akhir sering salah karena siswa kurang teliti), dan kebingungan terhadap rumus keliling, ada siswa yang menuliskan rumus luas sebagai rumus keliling. Pada kelas eksperimen, 94\% yang mengerjakan dengan benar, sedangkan dikelas kontrol $77 \%$ yang mengerjakan dengan benar. Dari gambar 1 di atas, dapat dilihat bahwa seluruh indikator tercapai dengan benar dan sesuai dengan kunci jawaban yang telah dibuat oleh peneliti.

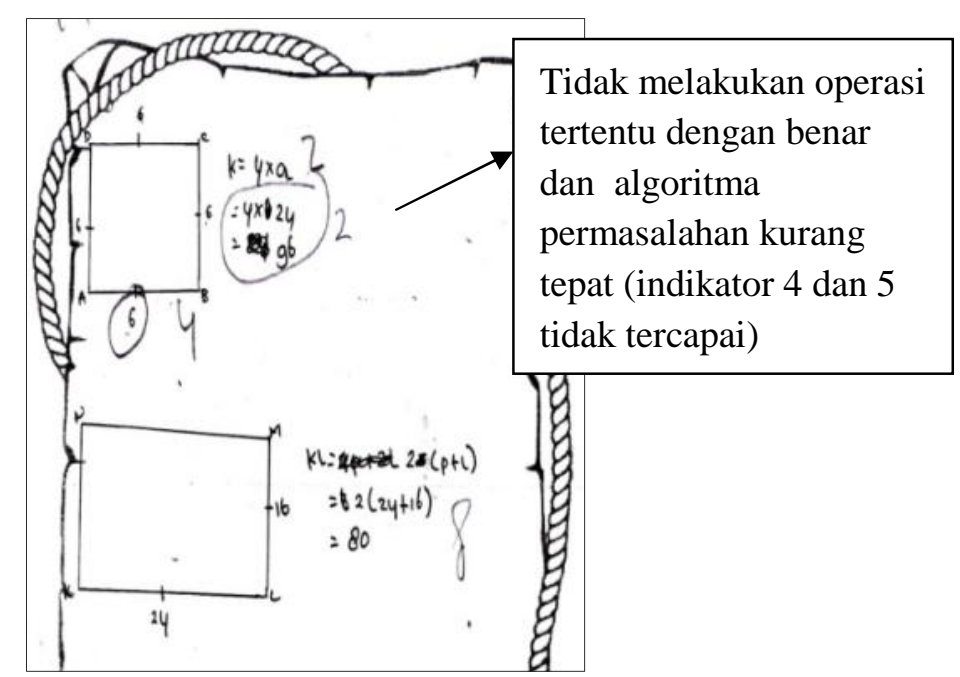

Gambar 2 Jawaban siswa kelas Kontrol soal posttest ke-1

Dari Gambar 2 di atas, dapat dilihat bahwa indikator menyajikan ulang konsep dan menyajikan dalam berbagai bentuk representasi matematis sudah tercapai meskipun belum dilakukan dengan baik, tetapi siswa tetap mendapatkan skor maksimal. Sedangkan, indikator menggunakan, memanfaatkan, dan memilih prosedur/operasi tertentu, serta mengaplikasikan konsep/algoritma pemecahan masalah tidak tercapai karena siswa kurang teliti pada proses memasukkan nilai pada rumus, siswa menggunakan rumus luas dulu (mengalikan dua sisi) kemudian baru memasukan nilai tersebut ke dalam rumus keliling, sehingga hasil akhirnya tidak benar. 


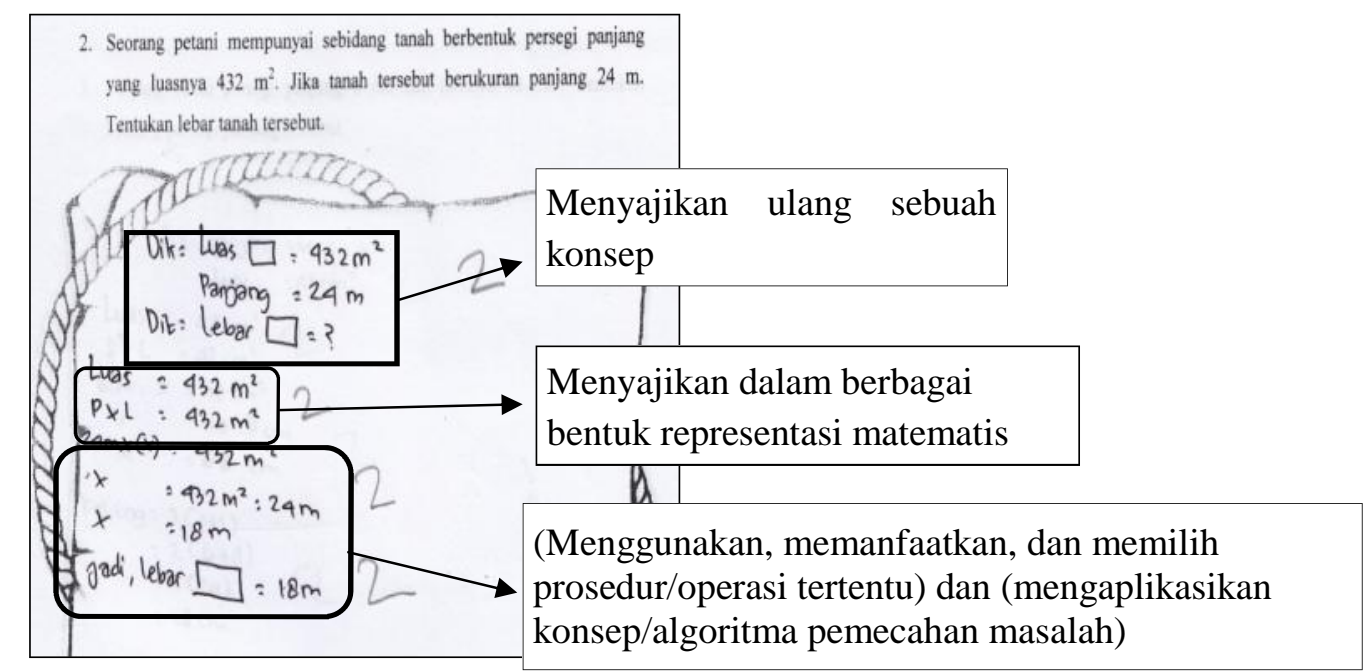

Gambar 3 Jawaban siswa kelas Eksperimen soal posttest ke-2

Soal ini tentang persegi panjang, dimana yang diketahui adalah luas persegi panjang sehingga siswa harus mencari lebar dari tanah yang berbentuk persegi panjang. Kesalahan yang terjadi pada kebingungan siswa tentang bagaimana cara untuk mencari lebar jika yang diketahui luasnya, ada siswa yang menuliskan rumus luas, dan kemudian mengalikan angka yang ada pada soal, serta kesalahan dalam menghitung. Pada kelas eksperimen ada $81 \%$ yang mengerjakan soal dengan benar, sedangkan dikelas kontrol ada $74 \%$ yang mengerjakan dengan benar. Dari Gambar 3 di atas, dapat dilihat bahwa seluruh indikator tercapai dengan benar dan sesuai dengan kunci jawaban yang telah dibuat oleh peneliti.

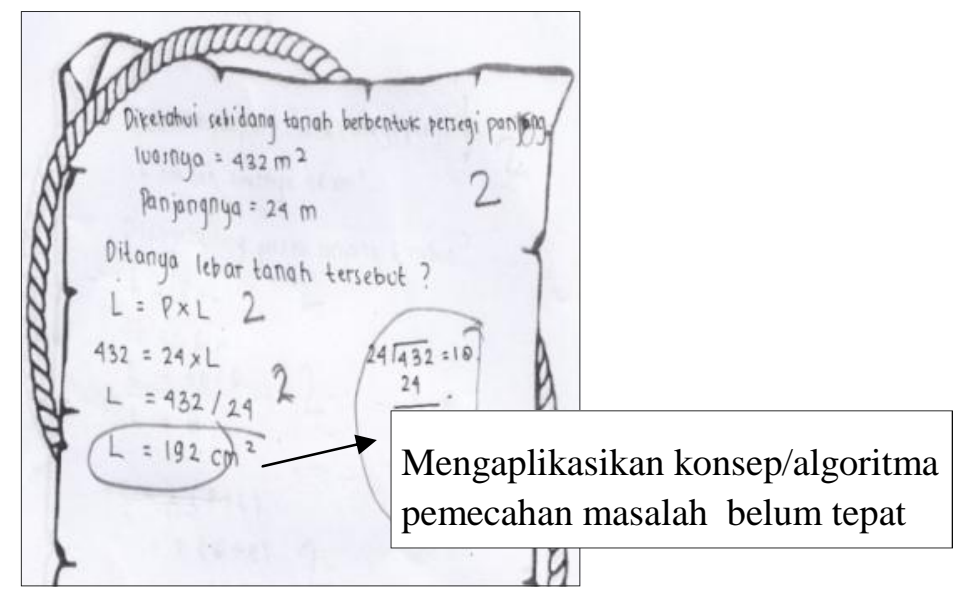

Gambar 4 Jawaban siswa kelas Kontrol soal posttest ke-2 
Dari Gambar 4 di atas, dapat dilihat bahwa indikator menyajikan ulang sebuah konsep, menyajikan dalam berbagai bentuk representasi matematis, menggunakan, memanfaatkan, dan memilih prosedur/operasi tertentu sudah tercapai dan dilakukan dengan baik. Sedangkan, indikator mengaplikasikan konsep/agoritma pemecahan masalah sudah tercapai tetapi belum tepat karena siswa tidak teliti dalam mengoperasikannya dan tidak fokus mengerjakannya pada situasi kelas yang cukup ribut sehingga hasil akhir yang dikerjakan siswa belum benar dan siswa hanya mendapatkan setengah dari skor maksimal.

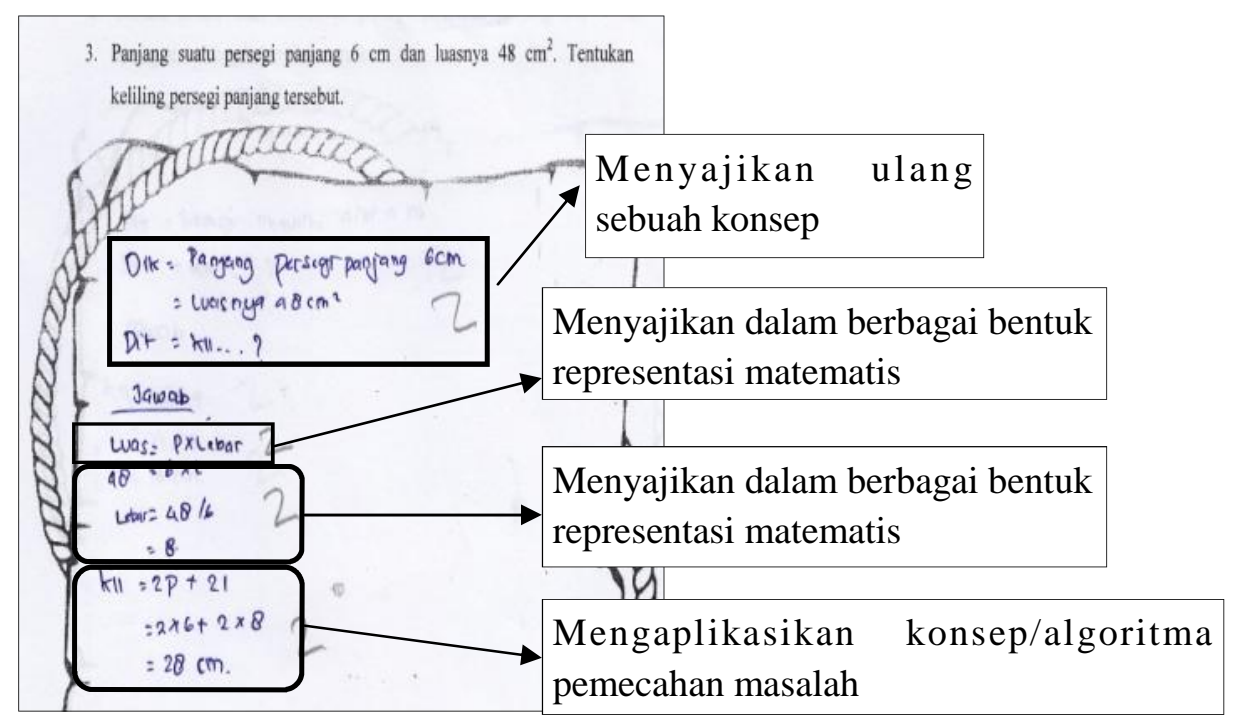

\section{Gambar 5 Jawaban siswa kelas Eksperimen soal posttest ke-3}

Soal ini juga tentang persegi panjang, yang diketahui adalah luas persegi panjang tetapi yang harus dicari adalah lebar dan keliling dari persegi panjang. Kesalahan yang terjadi hampir sama dengan soal posttest ke-2, karena cara menyelesaikan soal ini juga hampir sama dengan soal posttest ke-2. Pada kelas eksperimen ada $75 \%$ yang mengerjakan dengan benar, sedangkan dikelas kontrol ada $70 \%$ yang mengerjakan dengan benar. Dari Gambar 5 diatas, dapat dilihat bahwa seluruh indikator tercapai dengan benar dan sesuai dengan kunci jawaban yang telah dibuat oleh peneliti. 


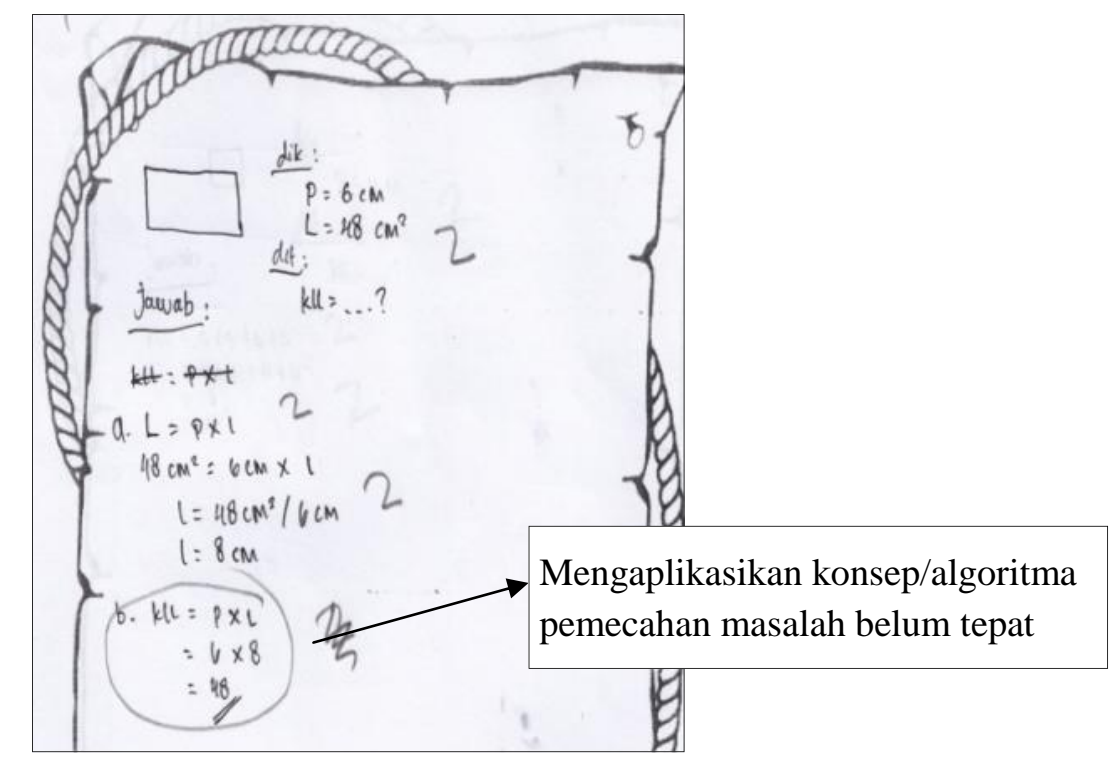

Gambar 6 Jawaban siswa kelas kontrol soal posttest ke-3

Dari Gambar 6 di atas, dapat dilihat bahwa indikator menyajikan ulang konsep dan menyajikan dalam berbagai bentuk representasi matematis, menggunakan, memanfaatkan, dan memilih prosedur/operasi tertentu sudah tercapai meskipun belum dilakukan dengan baik, tetapi siswa tetap mendapatkan skor maksimal. Sedangkan, indikator mengaplikasikan konsep/algoritma pemecahan masalah tidak tercapai, karena sebagian jawaban adalah hasil mencontek dari temannya, dan siswa memiliki kesalahan dalam memahami rumus keliling persegi panjang, hal itu dapat dilihat dari awal tulisan rumus keliling persegi panjang yang dicoret siswa. Sehingga, hasil akhirnya tidak benar. 


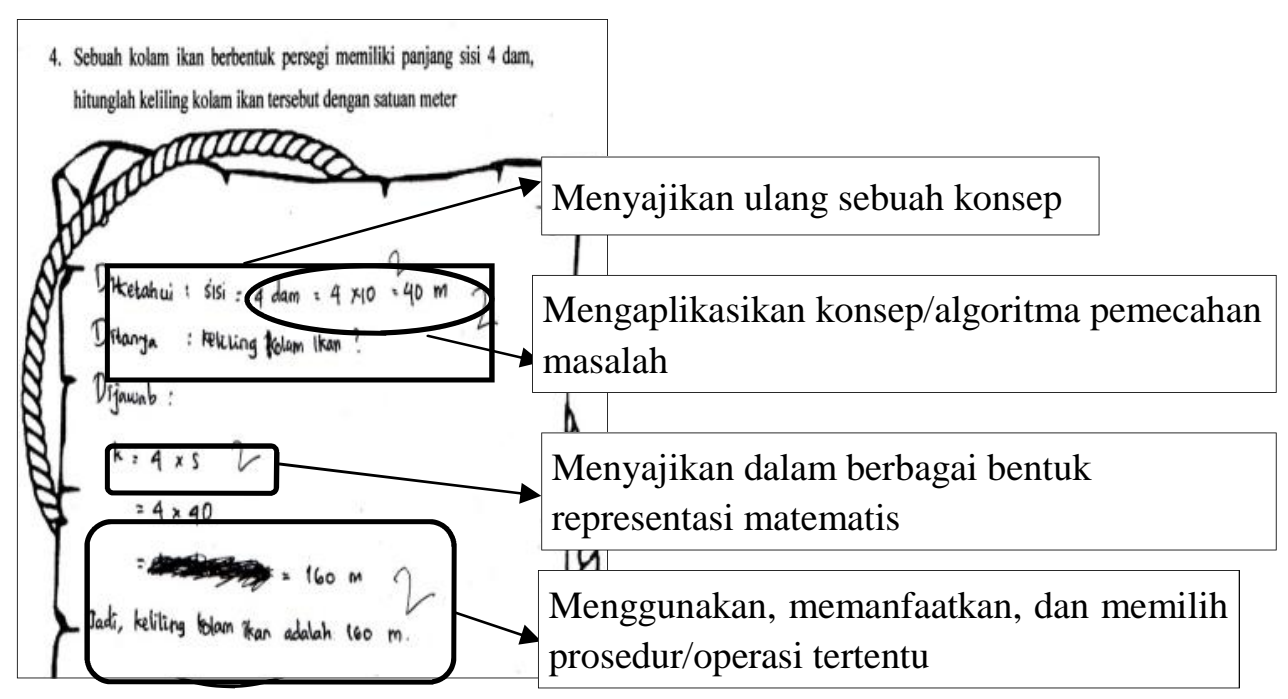

Gambar 7 Jawaban siswa kelas eksperimen soal posttest ke-4

Soal ini tentang persegi, soal ini bisa dikatakan soal berkategorikan mudah tetapi yang menjadi permasalahan justru karena soal ini mudah maka siswa tidak mengerjakan soal ini dengan teliti. Banyak siswa yang tidak membuat diketahui,ditanya, dijawab, dan tidak memberikan kesimpulan, serta tidak mengubah satuan dam menjadi meter. Pada kelas eksperimen ada $66 \%$ yang mengerjakan dengan benar, sedangkan dikelas kontrol ada 58\% yang mengerjakan dengan benar. Dari Gambar 7 diatas, dapat dilihat bahwa seluruh indikator tercapai dengan benar dan sesuai dengan kunci jawaban yang telah dibuat oleh peneliti.

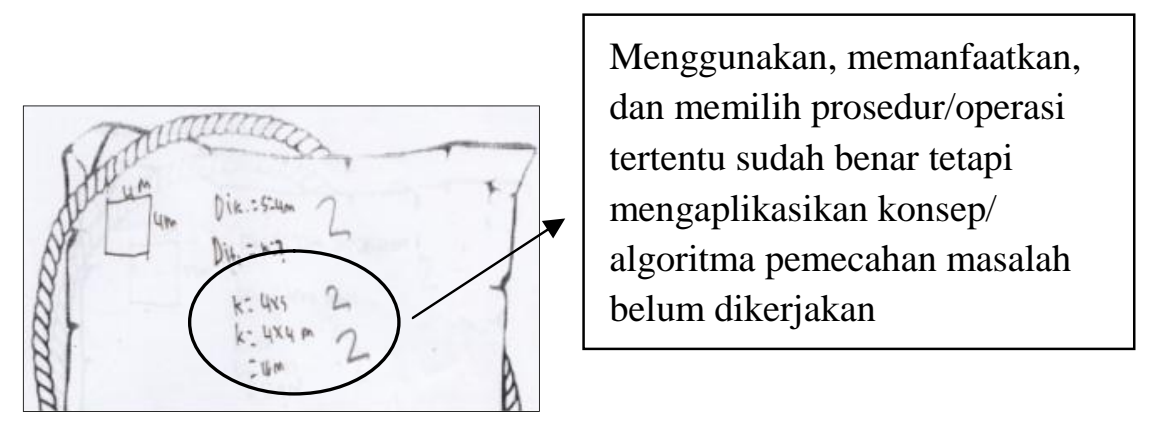

Gambar 8 Jawaban siswa kelas kontrol soal posttest ke-4 
Dari Gambar 8 di atas, dapat dilihat bahwa indikator menyajikan ulang konsep dan menyajikan dalam berbagai bentuk representasi matematis, menggunakan, memanfaatkan, dan memilih prosedur/operasi tertentu sudah tercapai meskipun belum dilakukan dengan baik, tetapi siswa tetap mendapatkan skor maksimal. Sedangkan, indikator mengaplikasikan konsep/pemecahan masalah tidak tercapai karena siswa memang belum mengerjakannya (mengubah dam menjadi $\mathrm{m}$ ), hal itu terjadi karena siswa tidak teliti dalam membaca soal.

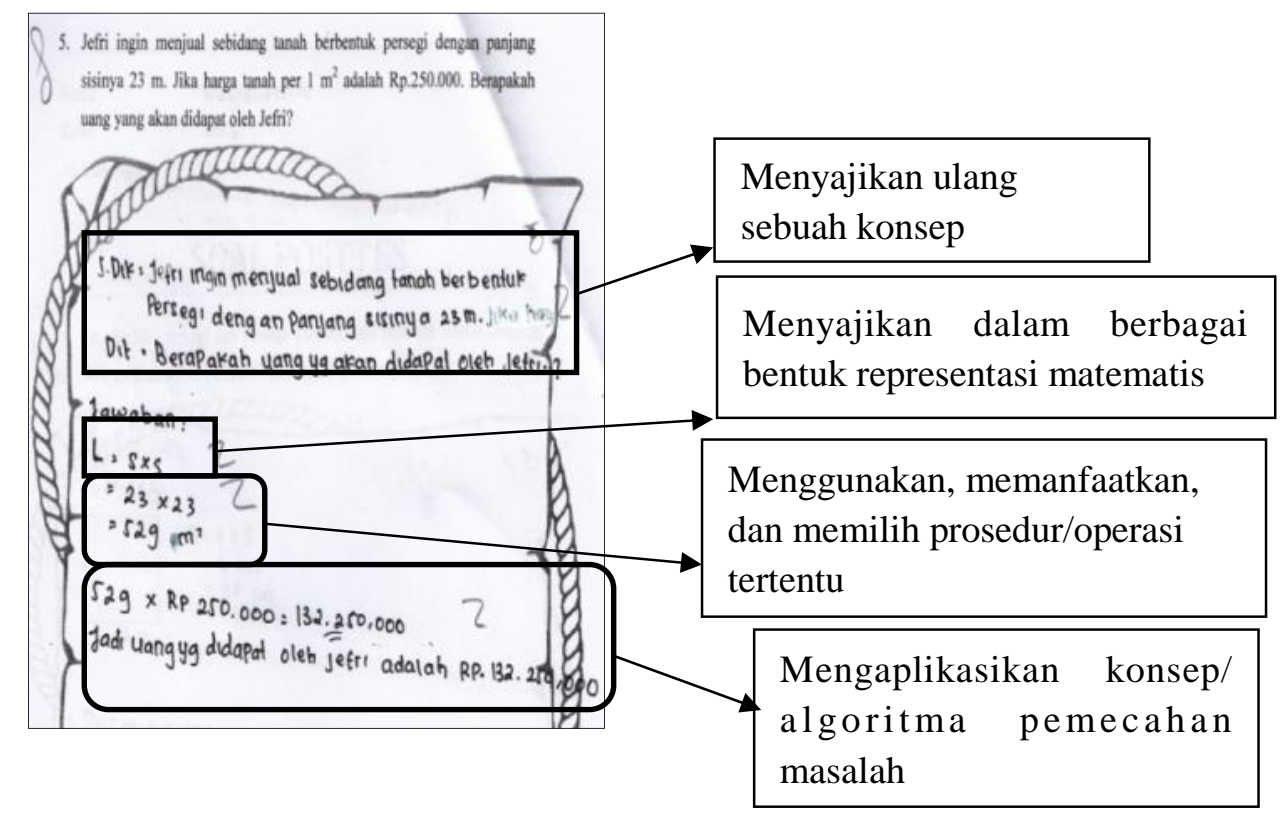

\section{Gambar 9 Jawaban siswa kelas eksperimen soal posttest ke-5}

Soal postest nomor 5 tentang persegi yang berhubungan dengan kehidupan seharihari (harga tanah). Kesalahan yang muncul adalah kebingungan siswa dalam menentukan dan menghitung hasil akhir, ada siswa yang langsung mengalikan sisi dengan harga tanah per meter tanpa mencari luasnya terlebih dahulu. Pada kelas eksperiman ada $75 \%$ yang mengerjakan dengan benar, sedangkan dikelas kontrol ada 64\% yang mengerjakan dengan benar. Dari Gambar 9 di atas, dapat dilihat bahwa seluruh indikator tercapai dengan benar dan sesuai dengan kunci jawaban yang telah dibuat oleh peneliti. 


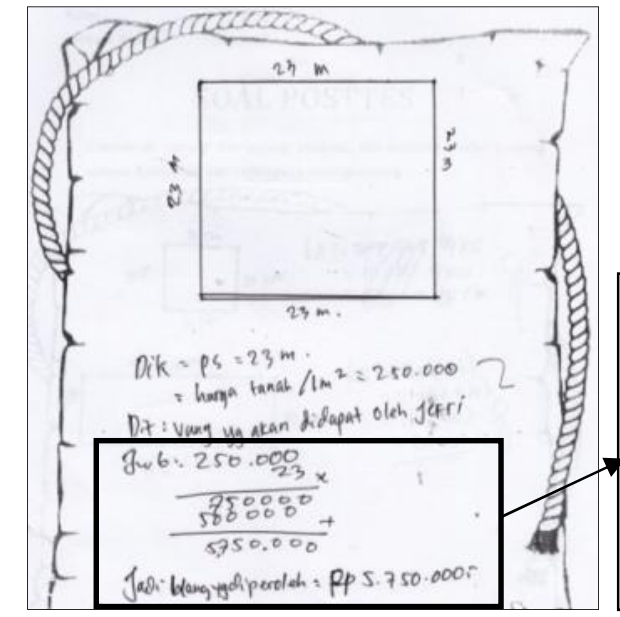

Tidak menuliskan rumus (tidak menyajikan dalam berbagai bentuk representasi matematis), operasi tertentu tidak tepat dan mengaplikasikan konsep/algoritma pemecahan masalah juga tidak tepat

\section{Gambar 10 Jawaban siswa kelas kontrol soal posttest ke-5}

Dari Gambar 10 di atas, dapat dilihat bahwa indikator menyajikan ulang sebuah konsep sudah tercapai. Sedangkan, indikator menyajikan dalam berbagai bentuk representasi matematis tidak tercapai karena siswa tidak menyelesaikan soal menggunakan rumus. Indikator menggunakan, memanfaatkan, dan memilih prosedur/ operasi tertentu, serta mengaplikasikan konsep/pemecahan masalah tidak tercapai karena siswa tidak teliti dan tidak memahami soal tersebut, sehingga siswa tidak tepat dalam menyelesaikannya.

Dilihat dari hasil posttest pada kelas eksperimen maupun kelas kontrol terdapat perbedaan pada nilai yang didapatkan oleh siswa. Nilai tertinggi dan terendah yang didapat siswa pada kelas eksperimen secara berturut-turut adalah 100 dan 19, dengan ratarata nilai sebesar 80,61 . Sedangkan nilai tertinggi dan terendah yang didapat siswa pada kelas kontrol secara berturut-turut adalah 92 dan 4, dengan rata-rata nilai sebesar 68,38. Data tersebut menunjukkan bahwa kelas eksperimen hasil posttestnya lebih baik dari kelas kontrol yang berarti ada pengaruh strategi Think Talk Write terhadap kemampuan pemahaman konsep pada pembelajaran matematika di MTs N 2 Model Palembang. Hal ini pun diperkuat peneliti dengan melakukan uji hipotesis menggunakan uji-t, data yang diperoleh adalah $t_{\text {hitung }}>t_{\text {tabel }}(2,544>1,6735)$, maka $H_{a}$ diterima dan $H_{0}$ ditolak yang berarti ada pengaruh strategi Think Talk Write (TTW) terhadap kemampuan pemahaman konsep pada pembelajaran matematika di MTs N 2 Model Palembang. 


\section{KESIMPULAN}

Berdasarkan hasil penelitian yang dilaksanakan dengan menggunakan strategi Think Talk Write (TTW) pada pembelajaran matematika materi persegi dan persegi panjang dapat disimpulkan bahwa: Dari hasil analisis data yang dilakukan pada data posttest yang digunakan untuk menguji hipotesis penelitian yakni berarti ada pengaruh strategi Think Talk Write (TTW) terhadap kemampuan pemahaman konsep pada pembelajaran matematika di MTs N 2 Model Palembang. Hal tersebut ditunjukkan dari hasil perhitungan menggunakan uji " $\mathrm{t}$ " yang dilakukan pada kelas VII MTs N 2 Model Palembang diperoleh nilai $t_{\text {hitung }}=2,544$ dan $t_{\text {tabel }}=1,673$. Karena $t_{\text {hitung }}>t_{\text {tabel }}(2,544>$ 1,673), maka $\mathrm{H}_{\mathrm{a}}$ diterima dan $\mathrm{H}_{0}$ ditolak yang berarti berarti ada pengaruh strategi Think Talk Write (TTW) terhadap kemampuan pemahaman konsep pada pembelajaran matematika di MTs N 2 Model Palembang.

\section{SARAN}

Pada penelitian ini, peneliti tentunya menemukan beberapa kekurangan, dan menyimpulkan bahwa strategi Think Talk Write (TTW) disarankan dapat diterapkan pada materi lain, menggunakan soal open-ended dan dapat mengukur kemampuan matematika yang lain, contoh: komunikasi dan keaktifan siswa. 


\section{DAFTAR PUSTAKA}

Arikunto, S. (2013). Dasar-dasar Evaluasi Pendidikan. Jakarta: Bumi Aksara.

Arikunto, S. (2010). Prosedur Penelitian Suatu Pendekatan Praktik. Jakarta: Rineka Cipta.

Baiquni, A. (1994). Al-Qur'an Ilmu Pengetahuan dan Teknologi. Jakarta: PT. Dana Bhakti Prima Yasa.

Hinayah, M. (2010). Penggunaan Lembar Kerja Siswa dengan Strategi Think Talk Write (TTW) untuk Meningkatkan Keaktifan dan Pemahaman Konsep pada Materi Pokok Segi Empat (Studi Tindakan pada Peserta Didik Kelas VII D SMP Salafiyah Kauman Pekalongan Tahun Pelajaran 2009/2010. In Skripsi. Semarang: Institut Agama Islam Negeri Walisongo.

Kiftiyah, N. M., Yudyanto, \& Sutopo. (2014). Identifikasi Pemahaman Konsep Siswa Kelas VIII SMP Negeri 4 Malang Semester II dalam Materi Getaran dan Gelombang Tahun Ajaran 2013/2014. Jurnal Online Universitas Negeri Malang , 2 (1), $1-11$.

Septiani, T. (2015). Pengaruh Stategi Think Talk Write dengan Menggunakan Mind Map terhadap Pemahaman Konsep Matematika di SMP N 48 Palembang. In Skripsi. Palembang: FKIP Universitas PGRI.

Sugiyono. (2013). Metode Penelitian Kuantitatif Kualitatif dan R\&D. Bandung: Alfabeta. 